\title{
A study on critical success factors on building IT based flat organization: A case study of Mellat Bank
}

\author{
Farajollah Rahnavard $^{\mathrm{a}}$ and Azadeh Asefikia ${ }^{\mathrm{b}^{*}}$
}

${ }^{a}$ Institute of Research Management and Planning, Tehran, Iran

${ }^{b}$ Msc. Student, MBA, University of Tehran, Aras International Campus, Jolfa, Iran

\section{H R O N I C L E A B S T R A C T}

Article history:

Received January 14, 2014

Accepted 10 June 2014

Available online

June 122014

Keywords:

Strategic planning

Principle component analysis

Information technology

\section{Introduction}

Strategy planning plays an important role on development of business organizations and it is important to apply reliable long-term plans to reach organizational objectives. There are literally different strategies where people could simply switch from one to another one. One of the key strategies to have successful firm is to make necessary changes on firm to have flat organization (Porter \& Siegel, 1965; Garzo Jr. \& Yanouzas, 1969; Goh, 1998). According to Ghiselli and Siegel (1972), the structure of a firm is associated with the nature of the distribution of the units and positions within it, and to the nature of the relationships among those units and positions. A flat organization is a firm that has an organizational structure with few or no levels of middle management between employee and executives. The idea is to take advantage of well-trained workers when they are more directly involved in the decision making process, rather than closely supervised by various layers of management. A flat firm model promotes employee involvement through a

*Corresponding author

E-mail addresses: A.ASEFIKIA@UT.AC.IR (A. Asefikia)

(c) 2014 Growing Science Ltd. All rights reserved.

doi: 10.5267/j.msl.2014.6.023 
decentralized decision-making process. By assessing the level of responsibility of baseline employees and removing layers of middle management, comments and feedback reach all personnel involved in decisions very quickly. There are literally many studies associated with flat organizations.

Seppälä (2004), for instance, investigated the roles and job characteristics of supervisors and other white-collar staff connected with production in eight manufacturing and printing firms that had applied the principles of a lean organization and advanced IT in the 1990s. In their study, they interviewed 212 employees including production managers and employees from various organizational levels and phases of the production process. They reported that the number of first line supervisors had decreased in all the studied firms, and in some manufacturing firms, there were no first line supervisors in the production departments at all. In some firms, the title of the previous supervisors had been changed to manufacturing manager, their responsibility area became larger and they were in charge of a broader manufacturing area or a product shop. It appeared that the supervisors' careers in the firms taking part in this study had developed mostly in a positive direction. However, at the same time, the amount of work had increased, more specifically in production in the manufacturing industry.

In early eighties, the management team of the organization of the Management Systems Laboratories (MSL) of the Virginia Polytechnic Institute and State University, USA, changed its structure from a standard matrix unit to a flat organization. The flat organization created more negative impacts on the organization and its objectives than positive effects. One year later, the flat organization was changed to a standard hierarchy, and most of the negative effects were overcome. Kurstedt Jr et al. (1991) is believed to be the first experience with a type of flat organization, why that organization was converted to, what worked and what did not, why the organization was converted away from, what was learned from the experience, and what the authors recommend for research organizations considering flat firms. Ghiselli and Siegel (1972) presented a comprehensive survey on leadership and managerial success in tall and flat organization structures.

\section{The proposed study}

The proposed study of this paper applies factor analysis to detect critical success factors associated with internal, external components influencing on having flat IT based organization, and the study has accomplished in bank Mellat. The sample size is calculated as follows,

$$
n=\frac{N \times z_{\alpha / 2}^{2} \times p \times q}{\varepsilon^{2} \times(N-1)+z_{\alpha / 2}^{2} \times p \times q},
$$

where $N$ is the population size, $p=1-q$ represents the yes/no categories, $z_{\alpha / 2}$ is CDF of normal distribution and finally $\varepsilon$ is the error term. Since we have $p=0.5, z_{\alpha / 2}=1.96$ and $N=1500$, the number of sample size is calculated as $n=306$. The study designed a questionnaire and distributes it among 320 people and managed to collect 308 properly filled ones. There are two questionnaires, one for internal and the other for external factors. In terms of internal factors, the questionnaire contains 20 questions. Kaiser-Meyer-Olkin (KMO) and Bartlet tests are 0.915 and 2630, respectively, which confirm the overal questionnaire. In terms of external factors, the questionnaire contains 20 questions. Kaiser-Meyer-Olkin (KMO) and Bartlet tests are 0.900 and 23260, respectively, which confirm the overal questionnaire.

\section{The results}

In this section, we present details of our findigns in terms of internal/external factors.

\subsection{Internal factors}

The study has applied factor analaysis through principle component analysis to extract impoartant internal factors and the results are summarized in Table 1 as follows, 
Table 1

The summary of principal component analysis after rotation for internal process

\begin{tabular}{|c|c|c|c|}
\hline Description & $\begin{array}{l}\text { Processes and the electronic decision } \\
\text { making }\end{array}$ & $\begin{array}{l}\text { Teaching and Electronic } \\
\text { Learning }\end{array}$ & $\begin{array}{l}\text { Work in } \\
\text { IT }\end{array}$ \\
\hline Employees do teleworking & 0.476 & & 0.636 \\
\hline All decisions are made in group & 0.42 & & 0.696 \\
\hline Information technology must be used for decision making & & & 0.516 \\
\hline There is an internet system & & & 0.745 \\
\hline Internet is used for harmony within organizations & & & 0.769 \\
\hline All tasks are assigned electronically & 0.618 & & 0.361 \\
\hline A software group is used for accomplishment of tasks & & & 0.61 \\
\hline Virtual units are used to accomplish tasks & & & 0.666 \\
\hline Virtual teams are used to accomplish tasks & 0.57 & & 0.361 \\
\hline Management system is used for decision making & 0.674 & & \\
\hline Management team emphasis on electronic monitoring & & & 0.757 \\
\hline Bank uses electronic methods to order administration & 0.366 & & 0.603 \\
\hline Bank uses electronic methods for advertisement & & & 0.558 \\
\hline Electronic contracts are used to accomplish contracts & & & 0.616 \\
\hline Training tasks and processes are performed electronically & & 0.698 & \\
\hline There is a portal system to accomplish tasks & & 0.775 & \\
\hline Electronic learning methods are used for training & & 0.774 & \\
\hline Management is executed in part of organization, & & 0.56 & \\
\hline The bank uses learning management system for training & & 0.666 & \\
\hline Enterprise resources planning is used to accomplish tasks & 0.436 & 0.554 & \\
\hline Value & 41.764 & 50.645 & 56.253 \\
\hline Variance & 8.353 & 1.776 & 1.122 \\
\hline Accumulated & 8.882 & 5.608 & 41.764 \\
\hline
\end{tabular}

As we can observe from the results of Table 1, there are three factors including Processes and the electronic decision making, Teaching and Electronic Learning and Work in IT.

\subsection{External factors}

The study has also used factor analaysis through principle component analysis to extract impoartant external factors and the results are given in Table 2 as follows,

Table 2

The summary of principal component analysis for external factors

\begin{tabular}{|c|c|c|c|c|}
\hline Item & $\begin{array}{l}\text { Electronic } \\
\text { Supply }\end{array}$ & $\begin{array}{c}\text { IT } \\
\text { structure }\end{array}$ & $\begin{array}{l}\text { Appropriate IT } \\
\text { usage }\end{array}$ & $\begin{array}{c}\text { Electronic } \\
\text { Communication }\end{array}$ \\
\hline Organization uses Internet to provide services & & & & 0.709 \\
\hline Organization uses appropriate SCM/CRM & & & & 0.747 \\
\hline Appropriate CRM is held among different suppliers & & & 0.41 & 0.702 \\
\hline Organization uses network structure to accomplish tasks & & & 0.698 & \\
\hline Video conferences are used for communication between different & 0.577 & & 0.375 & \\
\hline Managers support electronic communications & 0.713 & & & \\
\hline A modern communication is held among various customers & 0.598 & & 0.599 & \\
\hline Most tasks depend on electronic services & 0.351 & & 0.68 & \\
\hline Support and administrative units exist & 0.648 & & & \\
\hline Electronic consumer response units exist & 0.704 & & & \\
\hline Software packages exist to take care of documents & 0.606 & & & \\
\hline Internal networks exist & 0.535 & & & \\
\hline All software packages are upgradable and compatible with new & 0.444 & 0.484 & & \\
\hline Information system with supplementary documents exists & & 0.571 & & \\
\hline Security access to document exists & & 0.647 & & \\
\hline Necessary hardware and software exists within organizations & & 0.533 & & \\
\hline The capability on work over the internet exists & & 0.607 & & \\
\hline Video conferences are used for external/internal communications & & 0.639 & & \\
\hline Value & 36.633 & 44.397 & 51.16 & 56.729 \\
\hline Variance & 36.633 & 7.765 & 6.762 & 5.57 \\
\hline Accumulated variance & 6.594 & 1.398 & 1.217 & 1.003 \\
\hline
\end{tabular}


Based on the results of Table 2, there are four factors influencing the success of having flat IT based organization including Electronic Supply, IT structure, Appropriate IT usage and Electronic Communication.

\section{Conclusion}

In this paper, we have presented empirical investigation to detect important internal and external factors influencing critical success factors on having IT based flat organization. Using principal component analysis, the study has detected three internal as well as four external factors influencing on reaching successful IT based organization.

\section{Acknowledgement}

The authors would like to thank the financial support of Mellat Bank for accomplishment of this survey. We are also delighted for constructive comments on earlier version of this paper.

\section{References}

Garzo Jr, R., \& Yanouzas, J. N. (1969). Effects of flat and tall organization structure. Administrative Science Quarterly, 14(2).

Goh, S. C. (1998). Toward a learning organization: The strategic building blocks. SAM Advanced Management Journal, 63, 15-22.

Ghiselli, E. E., \& Siegel, J. P. (1972). Leadership and managerial success in tall and flat organization structures. Personnel Psychology, 25(4), 617-624.

Kurstedt Jr, H.A., Gardner, E. J., \& Hindman Jr, T. B. (1991). Design and use of a flat structure in a multiproject research organization. International Journal of Project Management, 9(4), 210-215.

Porter, L. W., \& Siegel, J. (1965). Relationships of tall and flat organization structures to the satisfactions of foreign managers. Personnel Psychology,18(4), 379-392.

Seppälä, P. (2004). Flat organizations and the role of white-collar employees in production. International Journal of Industrial Ergonomics, 33(1), 15-27. 